\title{
CASTILLA-LA MANCHA CITIES' COMPETITIVENESS IN INTELLECTUAL CAPITAL AS COMPARED TO OTHER SPANISH CITIES
}

Domingo NEVADO PEÑA

Faculty of Law and Social Sciences,

University of Castilla-La Mancha,

Ciudad Real, Spain

José Luis ALFARO NAVARRO, Víctor Raúl LÓPEZ RUIZ

Faculty of Economics and Business Administration,

University of Castilla-La Mancha,

Albacete, Spain

UDK: $304.3(460.28-21): 681.5$

Izvorni znanstveni rad

Primljeno: 9. 12. 2016.

Intellectual capital plays a central role in smart cities. The aim of this paper is to apply the recently developed model based on intellectual capital to measure and manage cities' competitiveness. This model is applied to cities in Castilla-La Mancha and another 19 Spanish cities, enabling a comparative analysis between these cities. To this end, the study presents a synthetic indicator that allows us to rank Spanish cities based on available information and propose a comprehensive management strategy that addresses both tangible and intangible competitiveness. From the results, it can be concluded that the cities of Castilla-La Mancha feature excellent human capacities and a good quality of life but that there is room for improvement in terms of city infrastructure and planning.

Keywords: smart city, knowledge city, intellectual capital, index, intangible, model, competitiveness

$\triangle$ Domingo Nevado Peña, Faculty of Law and Social Sciences, University of Castilla-La Mancha, Ronda de Toledo s/n, 13.071 Ciudad Real, Spain. 
The knowledge economy requires information and management systems that can evaluate and control intangible capital as a principal source of cities' competitiveness. This supposes a growing need for tools that enable a comprehensive future vision of: living conditions, comprehensive training and human development, as well as the available infrastructure and its efficient use, determining factors when it comes to choosing a residence.

In the knowledge society, information takes on a key role via information and communication technologies (ICT). These have helped create a new industrial model and the development of a new sector based on telecommunications and computer programmes, along with the application of these new technologies to different industries. This "revolution", such as it has been termed by many authors (Romer, 1986), has created a globalised world of greater competition, where a new division of labour has emerged based on global production chains with outsourced activities.

This knowledge economy is creating a situation in which the world's population is increasingly moving towards urban areas, with a growing number of associated problems including pollution, energy supply issues, security, overcrowding with its consequent impacts on security, health services, increased traffic, and so on. Consequently, a new dimension is emerging and cities must reorient themselves accordingly. This concept is becoming known as a "Smart City", in other words, a city that knows how to properly manage its intangibles. As the research and consulting organization Frost and Sullivan argued in 2013 (Frost \& Sullivan, 2013), eight key aspects define such a city: government, energy, buildings, infrastructure, mobility, technology, healthcare and intelligent citizens. That is to say, it is a metropolitan area that facilitates interaction between its citizens and various institutional, urban and technological elements, making everyday life easier and allowing access to education and culture, all tied in with sustainable environmental development. The accompanying use and application of ICT provides the city with an infrastructure that improves citizens' quality of life and encourages their active participation in city life, as well as enabling sustainable development and resource efficiency.

We thus have economically, socially and environmentally sustainable cities born out of a knowledge-based economy. Their defining characteristics are therefore related to the growth engines of this intellectual capital such as innovation, technology and human capital (the collective intelligence of the community). At the same time, it is crucial to know how to manage all this in such a way as to create a harmonious 
DRUŠ. ISTRAŽ. ZAGREB GOD. 26 (2017), BR. 4, STR. 519-538

NEVADO PEÑA, D. ALFARO NAVARRO, J. L., LÓPEZ RUIZ, V. R. CASTILLA-LA MANCHA. relationship between all these aspects. Consequently, we must establish measures for all endogenous factors, both tangible and intangible, of an economic and social space in order to estimate its capacity for growth and thus its competitiveness.

These measures are based on the elaboration of an index that has several dimensions and it can be classified according to the dimensions used as: general or growth; human development; and sustainability indices. In this paper, we apply a more general model proposed by López-Ruiz, Alfaro-Navarro, and Nevado-Peña (2014) for measuring and managing intellectual capital in Castilla-La Mancha and another 19 cities, with available information, in Spain. This model will help meet the challenges posed, moving from a traditional management to an integrated management. The different types of capital offer a medium- and long-term perspective and comprehensively address the people who occupy the space, the necessary infrastructure and appropriate management of the surroundings; we thus go beyond the concepts of human and social capital of smart cities employed by other academics. To this end, we first address the components of intellectual capital in cities, we then present the measurement model, and lastly, we carry out a practical comparative application between the cities of Castilla-La Mancha and other Spanish cities.

\section{A BRIEF REVIEW OF THE SMART CITY CONCEPT}

There is no universally-accepted definition of the Smart City concept, although Albino, Berardi, and Dangelico (2015) and Alfaro Navarro, López Ruiz, and Nevado Peña (2017) provide an extensive review of different interpretations of a Smart City. In this sense, it is important to bear in mind, as Caragliu, Del Bo, and Nijkamp (2011), Deakin and Al Waer (2011), Nam and Pardo (2011) and Townsend (2013) do, that there are a number of analogous terms to describe such cities, such as: "digital" (Ishida, 2002; Klein \& Kaefer, 2008); "intelligent" (Komninos, 2008; Nam \& Pardo, 2011; Washburn et al., 2010); "virtual" (Schuler, 2002), "wired" (Bakıc1 et al., 2012; Ghaffarian Hoseini et al., 2013); or "ubiquitous" (Greenfield, 2006; Townsend, 2013), but these refer to more specific facets of a city and are included in the broader concept of a Smart City.

Lombardi et al. (2011) state that a Smart City is one where investments in the human and social capital of modern ICT communication infrastructures provide the intelligence required underpinning economic growth and creating a platform of wealth creation, and where standards of governance support a high quality of living. It therefore represents an integrated vision of the term that goes beyond citizens' use of said technologies. 
DRUŠ. ISTRAŽ. ZAGREB GOD. 26 (2017), BR. 4, STR. 519-538

NEVADO PEÑA, D ALFARO NAVARRO, J. L., LÓPEZ RUIZ, V. R.: CASTILLA-LA MANCHA.
According to Deakin (2014) and his Triple Helix model, the Smart City concept refers to when the ICTs of future internet developments successfully embed the network society needs in order not only to generate intellectual capital, but also to cultivate environmental capacity, ecology and vitality, along with a decision-making system based on direct democracy and participatory governance. In this sense, Komninos (2008) makes the case that the intelligence of cities lies in the ever more efficient combination of digital telecommunication networks (the nerves), integrated with intelligence (the brain), sensors (the sense organs) and software. Similarly, Gooch, Wolff, Kortuem, and Brown (2015) and Coe, Paquet, and Roy (2001) believe that a Smart City is evolving towards a close integration of all the dimensions of human intelligence, collective intelligence and artificial intelligence within the city.

Returning to the Triple Helix model, Leydesdorff and Deakin (2011) consider that evolution towards an intelligent city depends on the interaction between the intellectual capital of universities, the industry of wealth creation and participatory governance as part of the democratic system that forms the rule of law. In the words of Deakin (2014), the goal, therefore, is to "generate intellectual capital and create wealth as much from the cultural attributes and environmental capacities of knowledge production, as the economic transactions which in turn relate such ICT-related developments to their emerging regional innovation systems".

In addition to new technologies, the role of human capital in developing smart cities with improved economic, social and environmental sustainability has been considered by Giffinger et al. (2007), Nam and Pardo (2011) or Neirotti et al. (2014).

Thus, Leydesdorff and Deakin (2011) highlight the importance of intellectual capital in Smart Cities and Dameri and Ricciardi (2015) suggest that the intellectual capital approach might be used to study the phenomenon of Smart Cities from a management perspective. Working towards the same goal of conceptual development and based on the intellectual capital approach, this paper aims to establish a measurement tool for Smart Cities that accounts for all the relevant dimensions.

These dimensions are key but there is no consensus in the literature as to the dimensions that should be considered; Barrionuevo, Berrone, and Ricart (2012), Chourabi et al. (2012), Kourtit and Nijkamp (2012), López-Ruiz et al. (2014), Angelidou (2015), and Dameri and Ricciardi (2015) all propose different kinds and numbers of dimensions based on intellectual capital. A review of the most widely-cited papers has been provided by Uziene (2013), who proposes three broad dimensions: human, structural and relational, and the applied model of López-Ruiz et al. (2014) and Alfaro Navarro et al. (2017), who use two dimensions for the human component and five for the structural one. 
In this paper, we use the dimensions suggested by López-Ruiz et al. (2014) and Alfaro Navarro et al. (2017) and propose a system of measuring and managing the intangible capital found in cities. Using this system, we are able to measure cities' intellectual capital and present an application to Spanish cities.

\section{COMPONENTS OF INTELLECTUAL CAPITAL IN KNOWLEDGE CITIES}

It is important to determine a methodology for calculating knowledge city index values or growth capacity; in this respect, the intellectual capital method can be a very valuable management tool. In this paper, we present a knowledge-based model for smart cities that draws on all sources of knowledge, and which allows us to define a city's growth capacity. The intellectual capital of a city is made up of knowledge in a number of different areas: human resources, infrastructure efficiency, mobility, accessibility, business, image, quality of life, tourism, innovation and environmental sustainability, all of which enable smart, sustainable growth and competitiveness capacity. This information is summarised in an index that determines competitiveness and ranks the cities analysed. To measure these intangibles for a city, we must refer to the following types of capital defined by López-Ruiz et al. (2014) (the individual and social capitals of López-Ruiz et al. (2014) are described in human capital):

- Social/human capital (HC) is essential for urban development; the concept of a knowledge-based city implies that its population grows intellectually, understanding how to adapt to their environment. Therefore, $\mathrm{HC}$ comprises individual resources (population and opening to foreign people and households); and social conditions (health, safety, labour market, education, and culture). Key features thus encompass social inclusion in terms of public services, where citizens are integrated through a single computer system, such as the use of smart cards, or using community and collaboration to solve problems (Komninos, 2013). Other important social factors include live cultures and evolutive capacities, as outlined by Carrillo (2004).

- Process capital: infrastructure efficiency, mobility and accessibility (PC). It is essential to establish excellent infrastructure and use it efficiently in order for a city to achieve healthy economic, social, and cultural development. Schiuma and Lerro (2008) examine infrastructural assets that are tangible in nature but which play a fundamental role in the diffusion of knowledge. However, process capital should also be linked to the local population's effective participation in local government through processes of open innovation and e-participation (Hollands, 2008), together with improvements in the collective intelligence of city institutions by means of e-government, 
DRUŠ. ISTRAŽ. ZAGREB GOD. 26 (2017), BR. 4, STR. 519-538

NEVADO PEÑA, D ALFARO NAVARRO, J. L., LÓPEZ RUIZ, V. R.: CASTILLA-LA MANCHA. with emphasis on citizen participation and co-design (Ballon, et al. 2011 and Deakin, 2007). In other words, this style of governance requires information to be openly shared via ICT, in order to facilitate citizens' involvement in the definition of public policies. Our position is in line with Komninos (2015), when he refers to smart environments, or intelligent cities, as environments of innovation and collaborative problem-solving. Although, our process capital also encompasses elements of planning, strategy and governance of intelligent cities.

- Commercial capital (CC) or establishing strategies in a competitive environment. Cities create strategies to boost local prosperity and sector competitiveness, using ICT to facilitate urban expansion by creating new businesses. Falconer and Mitchell (2012) considered that the economy is the key component in the development of smart cities with respect to companies or the government. It makes no sense to develop a "Smart City" that ignores business fundamentals. This dimension also forms one of the helixes in the neo-evolutionary model of Smart City proposed by Leydesdorff and Deakin (2011).

- Image capital: tourism, culture and quality of life conditions (IC). A good external image can help attract knowledge. In order to create such an image, improving quality of life should be paramount, along with efficiency. A Smart City should aim to provide benefits at all levels, with the biggest challenge being the effective implementation of all the large-scale solutions and technologies available. Falconer and Mitchell (2012) argue that the main obstacles to such an implementation tend to be governments, and in the case of some cities, a lack of funds.

- RED capital (RDC). A key role is played here by the creative and high-tech industries as they contribute to long-term urban growth. Training, adaptation and innovation help improve a city's intelligence and thus allow a quick, effective response to changing circumstances (Deakin \& Allwinkle, 2007). In short, this capital involves innovation in industries, knowledge workers and creation of knowledge-intensive companies. In addition, ICT takes on a special role by establishing a network of sensors to measure various parameters that facilitate better management of a particular area (Asín, 2011). Accordingly, collected data are transmitted in real time and are available to both the authorities and citizens.

- Environmental capital (EC), that is, sustainable cities. Sustainability is a key strategic component, along with educating people about leading less consumerist lifestyles, an energy mix with renewable energy, sustainable housing with smart energy meters to raise awareness about energy consumption, trash compactors, car charging stations, energy-saving lights, waste treatment, etc. All of these are vital to achieving and 
DRUŠ. ISTRAŽ. ZAGREB GOD. 26 (2017), BR. 4, STR. 519-538

NEVADO PEÑA, D. ALFARO NAVARRO, J. L., LÓPEZ RUIZ, V. R.

CASTILLA-LA MANCHA ensuring a safe, renewable exploitation of a city's natural heritage. Sustainability is not typically treated as an isolated dimension in the model, but rather as part of a capital whether instrumental as in Carrillo (2004) or relational as in Uziene (2013); however, in the model of López-Ruiz et al. (2014), it is already accounted for within the structural or "non-human" dimensions.

\section{MODEL FOR MEASURING CITIES' INTELLECTUAL CAPITAL}

Based on the approaches discussed in the previous section, and with reference to the model developed by López-Ruiz et al. (2014) with 19 dimensions and 73 indicators, we apply this model on cities' competitiveness. Following the intellectual capital (IC) approach developed by López-Ruiz et al. (2014), two major groups of intangible capital are identified: human capital (HC) and structural capital (SC) or "non-human" capital. They also include residual capital (RC) as a measurement or specification of the error for the capitals of each city "c", including two sources of error stemming from: a) the use of other possible intangible sources, and b) the method of measurement through the specified variables. For IC, we thus obtain Equation 1.

$$
\mathrm{IC}_{\mathrm{c}}=\sqrt[\alpha+\beta]{H C_{c}^{\alpha} \cdot S C_{c}^{\beta}}+R C_{c}
$$

To calculate intellectual capital, López-Ruiz et al. (2014) use a geometric mean with $\alpha$ and $\beta$ as weights, in order to obtain the two types of capital (human and structural). Given that it is impossible to directly assign weights to each indicator, they are transformed into principal components as follows in Equation 2:

$$
\mathrm{PC}_{\mathrm{ic}}=\sum_{i=1}^{k} u_{i} x_{i}
$$

where ui are the characteristic vectors of all the principal components and $x_{i}$ are the variables used to construct the different types of capital. Therefore, they use an objective procedure to establish the weights by means of a principal component analysis that enables us to assign weights to each indicator.

Once these components have been determined, López-Ruiz et al. (2014) construct an indicator for each type of capital "C" by weighting each component according to the percentage of variance retained by each, as shown in Equation 3.

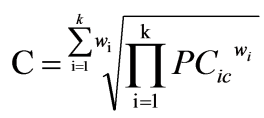

where $\mathrm{wi}_{\mathrm{i}}$ is the percentage of variance retained by each component (a total of $k$ variables). 
DRUŠ. ISTRAŽ. ZAGREB GOD. 26 (2017), BR. 4, STR. $519-538$

NEVADO PEÑA, D. ALFARO NAVARRO,' J. L., LÓPEZ RUIZ, V. R.: CASTILLA-LA MANCHA.
Lastly, the Knowledge Cities Index (KCI), as a geometric mean of human, structural and residual capitals, incorporates the main indicators, as it is justified in López-Ruiz et al. (2014). There are two relevant sources of human capital: individuals (in) and social (sc). Similarly, structural capital consists of the following types of capital: process (PC), commercial (CC), image (IC) research, development and innovation (RDC), and environmental capital (EC).

$$
\begin{aligned}
& K C I_{c}=\alpha \cdot\left[\sum_{i=1}^{h \alpha_{i}} \sqrt{\left(H C^{i n}{ }_{c}\right)^{\alpha_{1}} \cdot\left(H C^{s c}{ }_{c}\right)^{\alpha_{2}}}\right]+ \\
& +\beta \cdot\left[\sum_{i=1}^{k \beta_{i}} \sqrt{\left(P C_{c}\right)^{\beta_{1}} \cdot\left(C C_{c}\right)^{\beta_{2}} \cdot\left(I C_{c}\right)^{\beta_{3}} \cdot\left(R D C_{c}\right)^{\beta_{4}} \cdot\left(E C_{c}\right)^{\beta_{s}}}\right]
\end{aligned}
$$

where $\mathrm{KCI}$ is the index defined for the cities "c", and $\alpha, \beta$ are the parameters for the components of capital estimated by means of statistical methods (principal component analysis). The residual principal is not included in Equation 4 because in order to measure $\mathrm{KCI}$, it is taken as zero; that is, the mean of the variable, normally distributed with zero mean, constant variance and no correlation.

\section{APPLICATION OF THE MODEL TO CITIES IN}

\section{CASTILLA-LA MANCHA AND COMPARISON AT A NATIONAL LEVEL}

Our intention below is to apply the model to 26 cities across Spain, in an exploratory and descriptive way (Figure 1).

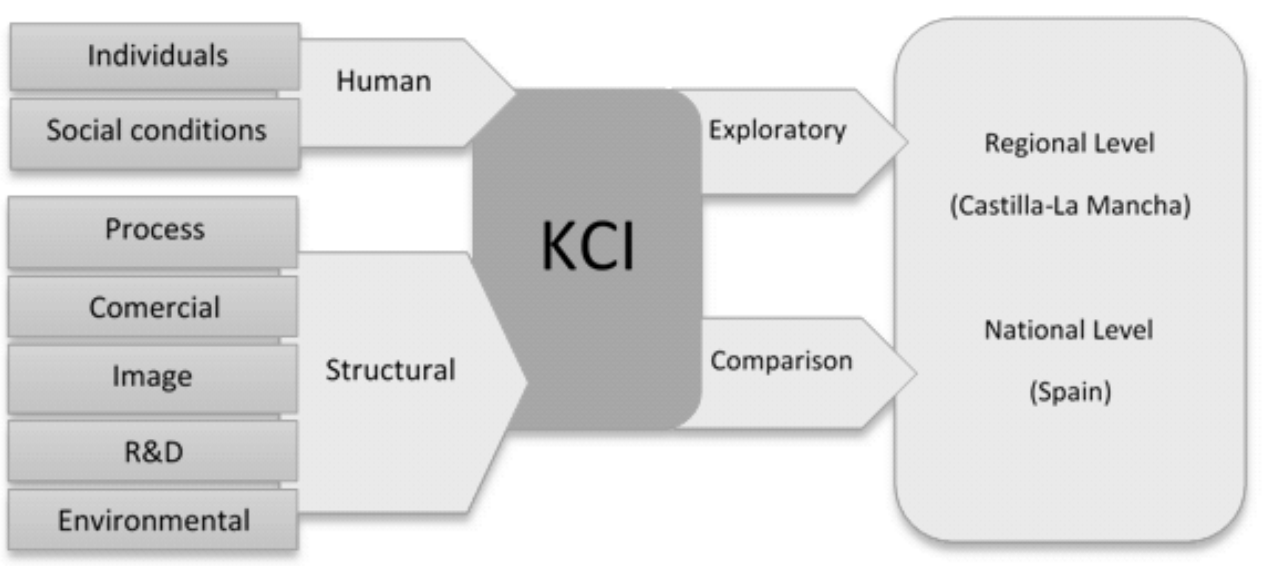

A FIGURE 1

Application Model
Since it is relatively difficult to obtain information at city level, the indicators have been selected according to the available information. Thus, the information was sourced from 
DRUŠ. ISTRAŽ. ZAGREB GOD. 26 (2017), BR. 4, STR. 519-538

NEVADO PEÑA, D. ALFARO NAVARRO, J. L., LÓPEZ RUIZ, V. R. CASTILLA-LA MANCHA...
Eurostat (Urban Audit Project) and was obtained directly for the seven cities in Castilla La Mancha: Albacete (AB), Ciudad Real (CR) and Puertollano (PU) in the province of Ciudad Real; and Cuenca (CU), Guadalajara (GU), Toledo (TO) and Talavera de la Reina (TR) in the province of Toledo. These cities were chosen in light of their size; along with the five provincial capitals we have also included Puertollano and Talavera de la Reina, all of which have more than 50,000 inhabitants. Finally, it is worth noting that our analysis focuses on 2011 due to the lack of more up-to-date information.

\section{Exploratory analysis of intellectual capital}

The intention of this initial exploratory analysis is to observe any anomalies in the information and compare the values with a standard city (Std) representing an average of the 26 cities chosen across Spain. In order to calculate this indicator, a mean was established for the value of the indicators that make up the calculation by dimensions, without objectively assigning any weight to the relevant indicators. In all cases, these values were rescaled to values of between 0 and 10 , with 0 representing the worst possible score and 10 the best. Nevertheless, the results for the dimensions and type of capital included in the KCI are presented in Tables 1 and 2, with conclusive information on the features of the Castilla-La Mancha cities versus those of the standard Spanish city.

Generally speaking (Table 1), the cities under study are efficient in terms of human capital; some of them do not show sufficient openness to the outside though the affordability of housing is above average. Regarding welfare, some specific features lead to inequalities in terms of health and education, with better results for the former. However, with some exceptions, access to culture and the range of culture on offer are above average which suggests that there is still a legacy effect linked to greater illiteracy in this region in the recent past. As for the labour market, bearing in mind that this information comes from 2011 which was at the beginning of the financial crisis, we can see that Puertollano, Guadalajara and Talavera are the lowest ranked cities.
(1) TABLE 1

Exploratory analysis indices normalised to a scale of $0-10$ : Human Capital

$\begin{array}{llllllll}\text { AB } & \mathrm{CR} & P U & \mathrm{CU} & \mathrm{GU} & \mathrm{TO} & \mathrm{TR} & \text { Std }\end{array}$

\begin{tabular}{lllllllll}
\hline Human Capital - Individual & & & & & & & & \\
$\quad$ Demographics (external openness) & 3.0 & 2.4 & 1.9 & 6.2 & 8.5 & 4.5 & 5.1 & 4.5 \\
$\quad$ Housing (access and cost) & 8.0 & 9.0 & 8.8 & 9.6 & 7.4 & 7.1 & 8.6 & 5.6 \\
$\quad$ Human Capital - Social & & & & & & & & \\
$\quad$ Health (mortality, hospital capacity) & 5.5 & 5.7 & 1.8 & 4.4 & 5.8 & 8.1 & 3.8 & 4.2 \\
$\quad$ Security (violent deaths, robberies...) & 5.9 & 6.1 & 6.0 & 6.5 & 5.9 & 6.5 & 5.8 & 5.3 \\
$\quad$ Work (jobs, entrepreneurship) & 5.6 & 4.7 & 2.2 & 7.5 & 2.5 & 5.3 & 3.7 & 5.0 \\
$\quad$ Education (at population level) & 3.6 & 3.5 & 3.5 & 3.5 & 3.7 & 3.9 & 3.0 & 4.8 \\
$\quad$ Culture (museums, libraries, cinemas...) & 3.7 & 6.7 & 4.2 & 5.4 & 2.5 & 5.4 & 2.2 & 3.3 \\
\hline
\end{tabular}


DRUŠ. ISTRAŽ. ZAGREB GOD. 26 (2017), BR. 4, STR. 519-538

NEVADO PEÑA, D ALFARO NAVARRO,', J. L., LÓPEZ RUIZ, V. R.: CASTILLA-LA MANCHA..

(1) TABLE 2

Exploratory analysis indices normalised to a scale of $0-10$ :

Structural Capital
With regard to structural capital (Table 2), we focus on its different components and dimensions, comparing the standard or representative city with each of the analysed cities. Both political and social processes are examined for the analysed cities, with better results for the former. It is worth noting the case of Puertollano, which reveals troubling results in both cases, although admittedly it was a depressed area in the period under study and has shown stable electoral results throughout its democratic history. With respect to commercial capital, the results are not good for Castilla-La Mancha cities; of those cities, Toledo, Albacete and Ciudad Real show the best business capacity. In relation to image capital, Toledo and Cuenca (both World Heritage Cities) clearly stand out in terms of the tourist dimension, and perform well overall in terms of quality of life, with respect to the determinants of income and public safety. With regard to technological capital, there are only two cases of note: Toledo and Ciudad Real. Lastly, the cities in question demonstrate great environmental concern, although actions relating to waste recycling could be improved.

\begin{tabular}{|c|c|c|c|c|c|c|c|c|}
\hline Dimension & $\mathrm{AB}$ & $\mathrm{CR}$ & $P U$ & $\mathrm{CU}$ & GU & TO & $T R$ & Std \\
\hline \multicolumn{9}{|l|}{ Process Capital } \\
\hline Political participation (electoral) & 7.0 & 7.0 & 1.8 & 7.3 & 10 & 9.4 & 6.9 & 5.7 \\
\hline Mobility and accessibility & 3.9 & 3.4 & 3.1 & 4.0 & 4.7 & 4.3 & 2.8 & 3.9 \\
\hline \multicolumn{9}{|l|}{ Commercial Capital } \\
\hline Business capacity (companies) & 5.4 & 4.4 & 0.5 & 3.6 & 2.3 & 4.5 & 2.9 & 4.1 \\
\hline $\begin{array}{l}\text { Business conditions (entrepreneurship, } \\
\text { access and technology) }\end{array}$ & 2.3 & 2.4 & 1.3 & 3.3 & 2.0 & 3.3 & 1.2 & 3.1 \\
\hline \multicolumn{9}{|l|}{ Image Capital } \\
\hline Tourism & 0.4 & 0.8 & 0.02 & 2.2 & 0.6 & 3.6 & 0.01 & 1.8 \\
\hline Culture & 3.7 & 6.7 & 4.2 & 5.4 & 2.5 & 5.4 & 2.2 & 3.3 \\
\hline Quality of life (income and security) & 5.0 & 5.3 & 5.3 & 5.6 & 6.0 & 5.6 & 5.1 & 5.1 \\
\hline \multicolumn{9}{|l|}{ R\&D Capital } \\
\hline R\&D (services and products) & 2.0 & 4.6 & 1.3 & 2.8 & 2.9 & 6.8 & 0.5 & 3.5 \\
\hline \multicolumn{9}{|l|}{ Environmental Capital } \\
\hline Pollution (gases) & 6.6 & 7.1 & 4.2 & 7.3 & 4.6 & 6.6 & 7.2 & 6.4 \\
\hline Water (efficient consumption) & 5.1 & 5.6 & 5.2 & 6.1 & 6.8 & 5.8 & 5.0 & 5.6 \\
\hline Waste and recycling & 5.0 & 5.2 & 5.2 & 4.2 & 4.8 & 1.2 & 3.4 & 5.5 \\
\hline Land use & 6.8 & 6.5 & 6.4 & 8.0 & 6.3 & 6.3 & 6.2 & 4.5 \\
\hline
\end{tabular}

This first analysis shows that the cities of Castilla La Mancha, with low levels of per capita GDP, have mean values (as yet unweighted) close to those of the standard city in some dimensions and below them in other aspects, as previously noted. 


\section{$\mathrm{KCl}$ results and comparison at national level}

After carrying out the above exploratory analysis, the detailed methodology is applied to the seven Castilla-La Mancha cities as part of the total study of 26 Spanish cities.

Table 3 shows the KCI results on a percentage scale (maximum 100 and minimum 0 ) for both the overall index as well as from a human and structural perspective, along with some descriptive statistics. From Table 3, we can draw our first conclusions about the knowledge index in Spain. There are no great differences in aggregate terms but the values for the coefficient of variation reveal that the components corresponding

(1) TABLE 3

$\mathrm{KCl}$ Spain/Castilla-La Mancha: General, Human and Structural to human capital are more dispersed than those on the structural side. In other words, quality of life and social conditions are more unequal than elements relating to infrastructure.

\begin{tabular}{|c|c|c|c|c|c|c|}
\hline \multirow[b]{2}{*}{ City } & \multirow[b]{2}{*}{ Intellectual } & \multicolumn{2}{|r|}{ Values } & \multicolumn{3}{|c|}{ Ranking $\mathrm{KCl}$} \\
\hline & & Human & Structural & Intellectual & Human & Structural \\
\hline Alicante & 46.50 & 48.93 & 42.89 & 18 & 12 & 19 \\
\hline Badajoz & 39.65 & 35.56 & 40.65 & 26 & 26 & 23 \\
\hline Barcelona & 59.10 & 65.87 & 56.37 & 1 & 1 & 2 \\
\hline Bilbao & 53.49 & 52.58 & 55.62 & 3 & 5 & 3 \\
\hline Córdoba & 42.00 & 39.13 & 42.34 & 24 & 23 & 21 \\
\hline Logroño & 47.83 & 49.80 & 45.13 & 14 & 9 & 17 \\
\hline Madrid & 57.58 & 60.69 & 57.47 & 2 & 2 & 1 \\
\hline Málaga & 44.58 & 41.20 & 46.24 & 21 & 22 & 16 \\
\hline Murcia & 40.41 & 36.44 & 41.48 & 25 & 25 & 22 \\
\hline Oviedo & 48.61 & 48.16 & 48.59 & 10 & 14 & 9 \\
\hline Palma de Mallorca & 48.75 & 50.39 & 46.70 & 9 & 8 & 14 \\
\hline Pamplona & 49.58 & 48.46 & 50.55 & 6 & 13 & 5 \\
\hline Santander & 48.54 & 49.50 & 47.09 & 11 & 11 & 13 \\
\hline Santiago de Compostela & 45.35 & 38.43 & 51.02 & 19 & 24 & 4 \\
\hline Sevilla & 46.51 & 44.59 & 47.26 & 17 & 20 & 12 \\
\hline Valencia & 50.56 & 53.35 & 48.08 & 4 & 4 & 10 \\
\hline Valladolid & 46.58 & 44.25 & 47.78 & 16 & 21 & 11 \\
\hline Vitoria & 48.44 & 47.33 & 48.99 & 12 & 17 & 8 \\
\hline Zaragoza & 50.50 & 51.16 & 50.04 & 5 & 6 & 6 \\
\hline Albacete & 44.74 & 47.07 & 40.61 & 20 & 18 & 24 \\
\hline Ciudad Real & 48.43 & 49.80 & 46.53 & 13 & 10 & 15 \\
\hline Cuenca & 47.19 & 50.95 & 42.55 & 15 & 7 & 20 \\
\hline Guadalajara & 48.80 & 53.97 & 43.44 & 8 & 3 & 18 \\
\hline Puertollano & 44.39 & 47.50 & 39.37 & 22 & 16 & 25 \\
\hline Talavera & 43.13 & 46.22 & 37.70 & 23 & 19 & 26 \\
\hline Toledo & 48.83 & 47.87 & 49.37 & 7 & 15 & 7 \\
\hline Average & 47.70 & 48.05 & 46.69 & & & \\
\hline Std. deviation & 4.38 & 6.61 & 5.01 & & & \\
\hline Coef. of variation & 0.09 & 0.14 & 0.11 & & & \\
\hline First quartile & 44.89 & 45.00 & 42.63 & & & \\
\hline Median & 48.13 & 48.69 & 46.90 & & & \\
\hline Third quartile & 48.82 & 50.81 & 49.27 & & & \\
\hline
\end{tabular}


DRUŠ. ISTRAŽ. ZAGREB GOD. 26 (2017), BR. 4, STR. 519-538

NEVADO PEÑA, D ALFARO NAVARRO, J. L., LÓPEZ RUIZ, V. R.: CASTILLA-LA MANCHA.
In terms of intellectual capital, Toledo, Guadalajara and Ciudad Real have values above the mean values for Spain, while Talavera de la Reina, Puertollano and Albacete fall below the national average. In addition, it is noteworthy that the highest index value for Castilla-La Mancha is that of Toledo, with a value in the third quartile of the distribution, that is, it lies in the top 25\% of cities in terms of highest index values.

With respect to human capital, Guadalajara shows the highest value, followed by Cuenca. Both cities are highly ranked at the national level, lying in the third quartile of the distribution. However, the values of Talavera de la Reina, Albacete, Puertollano and Toledo are all below the mean value for this indicator.

Lastly, the situation in relation to structural capital is more worrying given that only Toledo has a value above the national average. Moreover, Talavera de la Reina, Puertollano, Albacete and Cuenca rank among the lowest $25 \%$ of Spanish cities in terms of said capital.

In short, the general $\mathrm{KCI}$ values calculated are perfectly acceptable for Toledo and Guadalajara, but very unbalanced in the case of Guadalajara when comparing values of human and structural capital. Ciudad Real and Cuenca are also well-positioned, although the former shows better balance in terms of individual components. Albacete, Puertollano and Talavera come last. Figure 2 presents a graphical analysis of the ranking results and shows the worrying situation of the cities of Castilla-La Mancha in terms of structural capital: these cities are ranked poorly and Talavera de la Reina holds the worst position overall.

Likewise, Table 3 offers a comparative analysis based on the rankings of cities, according to the $\mathrm{KCI}$ results for the seven Castilla-La Mancha cities compared to the other nineteen Spanish cities. In other words, it shows the national position of the Castilla-La Mancha cities. It only features cities for which there is available data, however, it does include all the Autonomous Communities except the Canary Islands and all major Spanish cities in terms of population.

Analysing the rankings using Spearman's rank correlation coefficient, we can see that the rankings according to $\mathrm{KCI}$ and to human and structural capital are very similar, with coefficient values of 0.85 and 0.80 , respectively. However, when comparing the rankings according to the two main types of capital considered, we can see that although they are similar in many cases, the level of agreement between the two is not high with a coefficient value of 0.44 .

Barcelona, Madrid and Bilbao are the top ranked cities with the best $\mathrm{KCI}$ values, and are also well-balanced. In terms of human capital, which encompasses elements relating to demographics, welfare and quality of life, Guadalajara is 
DRUŠ. ISTRAŽ. ZAGREB GOD. 26 (2017), BR. 4, STR. 519-538

NEVADO PEÑA, D. ALFARO NAVARRO, J. L., LÓPEZ RUIZ, V. R.

CASTILLA-LA MANCHA.. ranked third nationally and Cuenca is seventh, with Barcelona occupying the top spot. However, it should be noted that differences between the Spanish cities in terms of human capital are very small overall, if we discount Badajoz. With regard to structural capital, all Castilla-La Mancha cities except for Toledo rank poorly.

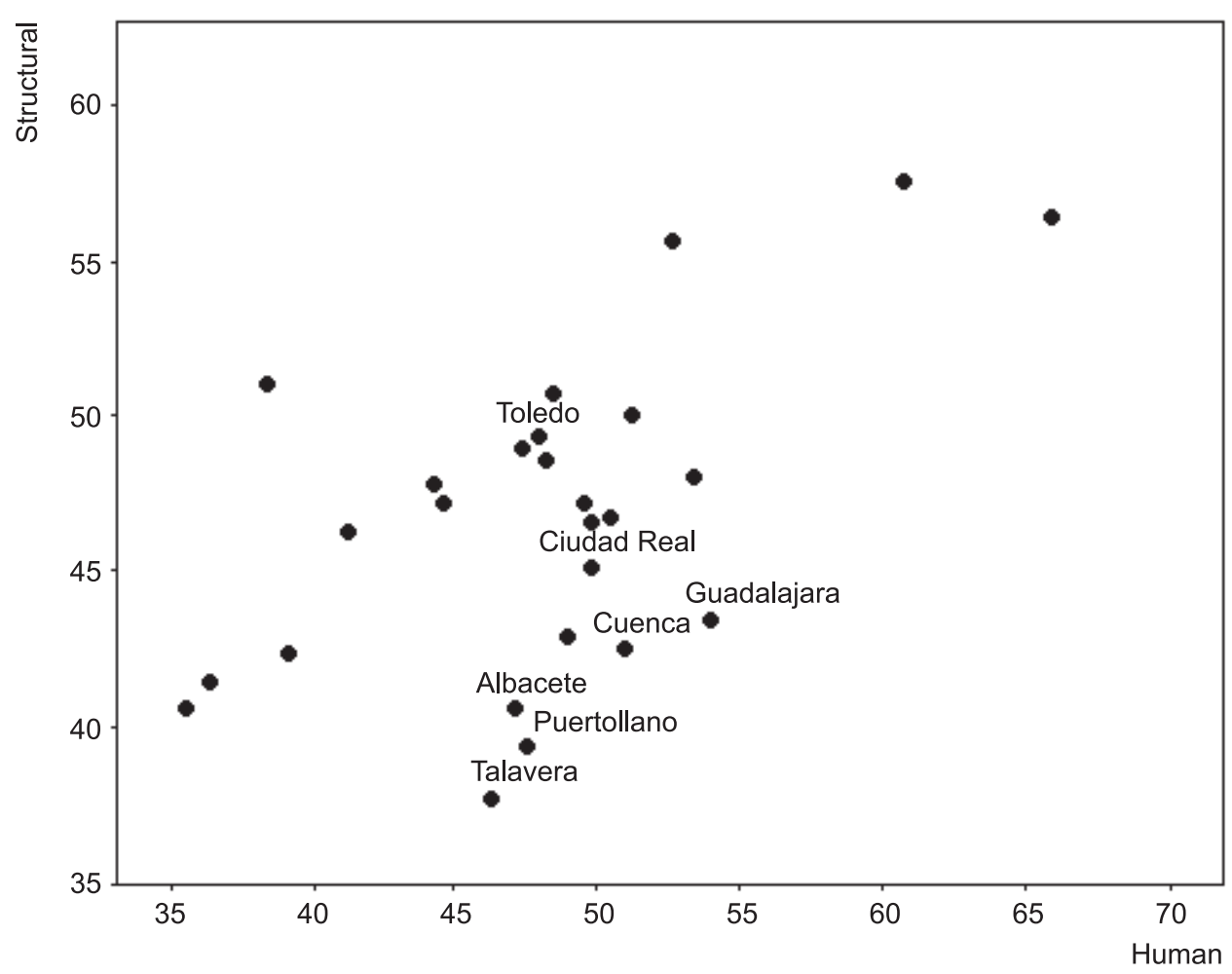

(1) FIGURE 2

Ranking of Castilla-La Mancha cities against Spanish cities

If we now perform a more detailed analysis of the different components of intellectual capital, we can see how, as we commented above, the Castilla-La Mancha cities are middle ranked with respect to the rest of Spanish cities in terms of human capital, thus indicating room for improvement. As such, it is interesting to determine where the greatest differences lie when analysing the index by components. To that end, Table 4 shows the indices for the subcapitals, i.e. the two aspects of human capital - individual and social - as well as process, commercial, image, R\&D and environmental elements of structural capital.

The values for the coefficient of variation for the indices disaggregated into human and structural elements reveal that the biggest difference in terms of human capital relates to the individual aspect and the openness of the population. $R \& D$ capital is the most unbalanced at the national level, followed by commercial capital. That is, there are major differ- 
ences between cities, in some cases driven by the larger size and income level of the city in question, which leads to greater potential for R\&D and commercial capital.

\begin{tabular}{|c|c|c|c|c|c|c|c|}
\hline City/Value & $\begin{array}{r}\mathrm{HC} \\
\text { adividual }\end{array}$ & $\begin{array}{c}\mathrm{HC} \\
\text { Social }\end{array}$ & Process & Commercial & Image & RDC & $\begin{array}{r}\text { Environ- } \\
\text { mental }\end{array}$ \\
\hline Alicante & 53.06 & 38.86 & 50.56 & 39.52 & 45.19 & 28.15 & 52.03 \\
\hline Badajoz & 30.66 & 46.90 & 51.68 & 36.14 & 38.73 & 27.48 & 47.68 \\
\hline Barcelona & 70.67 & 54.83 & 36.91 & 63.77 & 53.53 & 62.87 & 53.33 \\
\hline Bilbao & 52.36 & 53.20 & 47.78 & 61.44 & 50.01 & 55.10 & 65.47 \\
\hline Córdoba & 34.96 & 48.84 & 46.74 & 40.39 & 38.02 & 31.43 & 48.38 \\
\hline Logroño & 51.80 & 44.94 & 56.89 & 39.24 & 53.23 & 30.07 & 57.85 \\
\hline Madrid & 66.66 & 46.62 & 44.40 & 65.34 & 50.58 & 70.59 & 49.47 \\
\hline Málaga & 40.34 & 42.93 & 45.44 & 48.43 & 41.59 & 40.76 & 47.36 \\
\hline Murcia & 33.47 & 43.14 & 51.14 & 40.61 & 42.39 & 26.10 & 46.38 \\
\hline Oviedo & 45.39 & 54.79 & 53.29 & 53.43 & 44.66 & 34.66 & 62.95 \\
\hline Palma de Mallorca & 53.15 & 43.69 & 48.00 & 48.75 & 54.58 & 31.01 & 53.63 \\
\hline Pamplona & 49.24 & 46.51 & 57.23 & 52.65 & 54.67 & 39.76 & 61.25 \\
\hline Santander & 48.25 & 52.50 & 58.68 & 45.83 & 49.60 & 33.61 & 60.18 \\
\hline Santiago de Compostela & 34.58 & 47.35 & 58.62 & 41.95 & 49.66 & 55.59 & 59.41 \\
\hline Sevilla & 43.18 & 47.81 & 46.01 & 48.89 & 40.24 & 47.92 & 44.20 \\
\hline Valencia & 58.24 & 41.63 & 48.46 & 51.86 & 46.41 & 39.13 & 53.63 \\
\hline Valladolid & 43.99 & 44.66 & 52.32 & 45.86 & 50.18 & 41.81 & 52.38 \\
\hline Vitoria & 47.13 & 47.73 & 45.03 & 49.65 & 50.37 & 40.92 & 56.91 \\
\hline Zaragoza & 52.74 & 47.37 & 39.29 & 49.55 & 48.68 & 51.87 & 49.55 \\
\hline Albacete & 44.43 & 53.35 & 51.90 & 33.46 & 40.57 & 32.63 & 41.80 \\
\hline Ciudad Real & 46.33 & 58.21 & 52.26 & 35.93 & 41.65 & 55.39 & 44.11 \\
\hline Cuenca & 48.57 & 56.75 & 53.96 & 28.73 & 44.46 & 38.79 & 48.85 \\
\hline Guadalajara & 53.01 & 56.47 & 58.65 & 43.50 & 43.13 & 36.50 & 39.52 \\
\hline Puertollano & 42.39 & 59.80 & 46.45 & 38.34 & 37.69 & 27.70 & 36.75 \\
\hline Talavera & 42.58 & 54.91 & 54.20 & 31.58 & 39.43 & 20.42 & 43.47 \\
\hline Toledo & 44.07 & 57.01 & 57.42 & 37.41 & 42.71 & 65.85 & 44.85 \\
\hline Average & 47.36 & 49.65 & 50.51 & 45.09 & 45.84 & 41.00 & 50.82 \\
\hline Std. deviation & 9.09 & 5.68 & 5.71 & 9.31 & 5.30 & 13.06 & 7.30 \\
\hline Coef. of variation & 0.19 & 0.11 & 0.11 & 0.21 & 0.12 & 0.32 & 0.14 \\
\hline First quartile & 42.73 & 45.34 & 46.52 & 38.56 & 41.61 & 31.12 & 45.23 \\
\hline Median & 46.73 & 47.77 & 51.41 & 44.67 & 44.93 & 38.96 & 49.51 \\
\hline Third quartile & 52.64 & 54.82 & 54.14 & 49.62 & 50.14 & 50.88 & 56.09 \\
\hline
\end{tabular}

(1) TABLE 4

KCl Spain/Castilla-La Mancha: Human and Structural Capital disaggregated
Comparing mean human capital values for Spain with those for Castilla-La Mancha cities, we can see that the problems some cities face in this respect are a result of poor individual human capital. Only Cuenca and Guadalajara have values above the average, with the latter ranking among the top $25 \%$ of cities. However, in terms of social human capital, all Castilla-La Mancha cities perform well, with above-average values, and with all cities but Albacete among the top 25\%.

Regarding structural capital, the disaggregated values show room for improvement in all types of capital. The best 
DRUŠ. ISTRAŽ. ZAGREB GOD. 26 (2017), BR. 4 STR. 519-538

NEVADO PEÑA, D. ALFARO NAVARRO, J. L., LÓPEZ RUIZ, V. R. CASTILLA-LÁ MANCHA.. performance is recorded for process capital, for which all cities except Puertollano present values above the Spanish average. However, for commercial, image and environmental capital, all Castilla-La Mancha cities show below-average values; indeed, in many cases these values are within the bottom $25 \%$. With respect to R\&D, the situation is not much different, although in this case notable values are achieved by Ciudad Real and Toledo.

Based on this information, we can conclude that there are excellent human capacities in Castilla-La Mancha and a good quality of life, but that the infrastructure or configuration of cities can be improved. As regards structural capital, the cities of Castilla-La Mancha generally do not perform well, and specifically they fall short in the following areas:

- Albacete needs to improve its water and waste management, business conditions, innovation and development, and image.

- Ciudad Real has gaps in terms of environmental management, business conditions and image.

- Cuenca needs to take action to improve business conditions and image; it is a World Heritage City and as such it should be able to improve its value for image.

- Guadalajara needs to fundamentally improve its environmental management along with innovation and development, business conditions and image.

- Puertollano shows worrying values for all structural parameters or capital, with serious problems in terms of waste management, image, business and innovation.

- Talavera's situation is very similar to that of Puertollano, with big gaps in terms of technology and business conditions.

- The regional capital, Toledo, has acceptable values in terms of processes and technology, although it could show improvement in terms of image as it is a World Heritage City. It is, however, the city with the best structural conditions.

\section{CONCLUSIONS}

For the cities of the future, managing their intangibles will be key to sustainable growth and competitiveness. This creates a need for tools to facilitate the measurement of intellectual capital, which will provide decision-makers with a better understanding of such management in order to guide municipal policies. We therefore present a synthetic index for comparing and analysing cities' intellectual capital in its various com- 
DRUŠ. ISTRAŽ. ZAGREB GOD. 26 (2017), BR. 4, STR. 519-538

NEVADO PEÑA, D ALFARO NAVARRO', J. L., LÓPEZ RUIZ, V. R.: CASTILLA-LA MANCHA. ponents, based on two human dimensions and five structural ones that measure the effectiveness of actions in these areas. This idea is closely in line with Komninos (2008, 2013, 2015), Leydesdorff and Deakin (2011) and Deakin and Leydesdorff (2013), but we divide the notion of a Smart City into different key capitals and assign each one the appropriate weight and material composition.

We have applied this index to the major cities in Castilla-La Mancha with more than 50,000 inhabitants and also extended it to include all Spanish cities with available data.

Regarding relevant conclusions to be drawn from the analysis of the Castilla-La Mancha cities, it is particularly notable that these are low-income cities in terms of GDP per capita and they are roughly on a par with the representative city with respect to some dimensions, but lower in others. There is a correlation between a city's ability to generate intangibles and its competitiveness.

In terms of human capital, the Castilla-La Mancha cities are middle ranked with respect to other Spanish cities, leaving room for improvement. With respect to this capital, the major differences are found in terms of individual human capital and the openness of the population. In contrast, the situation is worse regarding structural capital, with R\&D capital clearly showing the greatest inequalities nationwide, followed by commercial capital. That is, there are major differences between cities, in some cases driven by the larger size and income level of the city in question. In short, in Castilla-La Mancha there are excellent human capacities with good quality of life but the infrastructure or configuration of cities can be improved.

Looking at the ranking of Spanish cities it can be seen that Barcelona, Madrid and Bilbao are the top ranked cities, with the best KCI values as well as being well balanced.

Lastly, policies targeted at Castilla-La Mancha cities should aim at improving the management of waste and pollutants, especially bearing in mind the fact that these are cities with small populations and vast natural surroundings. In the economic sphere, and compared to the national situation, the greatest need is for policies focusing on entrepreneurship and innovation. On the other hand, these cities boast excellent human capital, which they risk losing due to their proximity to cities that rank highly in terms of structural capital, such as Madrid or Valencia.

\section{ACKNOWLEDGEMENT}


Albino, V., Berardi, U., \& Dangelico, R. M. (2015). Smart cities: Definitions, dimensions, performance and initiatives. Journal of Urban Technology, 22(1), 3-21. https://doi.org/10.1080/10630732.2014. 942092

Alfaro Navarro, J. L., López Ruiz, V. R., \& Nevado Peña, D. (2017). The effect of ICT use and capability on knowledge-based cities. Cities, 60, 272-280. https://doi.org/10.1016/j.cities.2016.09.010

Angelidou, M. (2015). Smart cities: A conjuncture of four forces. Cities, 47, 95-106. https://doi.org/10.1016/j.cities.2015.05.004

Asín, A. (2011). Smart cities from Libelium allows systems integrators to monitor noise, pollution, structural health and waste management. Digital site 'Libelium', June 20, 2011. Available at http://www.libelium.com/ smart_cities/

Bakıcı, T., Almirall, E., \& Wareham, J. (2012). A smart city initiative: The case of Barcelona. Journal of the Knowledge Economy, 2(1), 1-14.

Ballon, P., Glidden, J., Kranas, P., Menychtas, A., Ruston, S., \& Van Der Graaf, S. (2011). Is there a need for a cloud platform for European smart cities? eChallenges e-2011. Florence, Italy.

Barrionuevo, J. M., Berrone, P., \& Ricart, J. E. (2012). Smart cities, sustainable progress. IESE Insight, (14), 50-57. https://doi.org/10.15581/ 002.ART-2152

Caragliu, A., Del Bo, C., \& Nijkamp, P. (2011). Smart cities in Europe. Journal of Urban Technology, 18(2), 65-82. https://doi.org/10.1080/ 10630732.2011.601117

Carrillo, F. J. (2004). Capital cities: A taxonomy of capital accounts for knowledge cities. Journal of Knowledge Management, 8(5), 28-46. https:// doi.org/10.1108/1367327041058738

Chourabi, H., Nam, T., Walker, S., Gil-Garcia, J. R., Mellouli, S., Nahon, K., Pardo, T. A., \& Scholl, H. J. (2012). Understanding smart cities: An integrative framework. Proceedings of the 45th Hawaii International Conference on System Sciences, 2289-2297. https://doi.org/ 10.1109/HICSS.2012.615

Coe, A., Paquet, G., \& Roy, J. (2001). E-governance and smart communities: A social learning challenge. Social Science Computer Review, 19(1), 80-93. https://doi.org/10.1177/089443930101900107

Dameri, R. P., \& Ricciardi, F. (2015). Smart city intellectual capital: An emerging view of territorial systems innovation management. Journal of Intellectual Capital, 16(4), 860-887. https:/doi.org/10.1108/ JIC-02-2015-0018

Deakin, M. (2007). From city of bits to e-topia: Taking the thesis on digitally-inclusive regeneration full circle. Journal of Urban Technology, 14(3), 131-143.

Deakin, M. (2014). Smart cities: The state-of-the-art and governance challenge. Triple Helix, 1(1), 1-16. https://doi.org/10.1186/s40604-0140007-9

Deakin, M., \& Al Waer, H. (2011). From intelligent to smart cities. Intelligent Buildings International, 3(3), 140-152. https://doi.org/10.1080/ 17508975.2011.586671 
DRUŠ. ISTRAŽ. ZAGREB GOD. 26 (2017), BR. 4, STR. 519-538

NEVADO PEÑA, D. ALFARO NAVARRO', J. L., LÓPEZ RUIZ, V. R.: CASTILLA-LA MANCHA..
Deakin, M., \& Allwinkle, S. (2007). Urban regeneration and sustainable communities: The role of networks, innovation and creativity in building successful partnerships. Journal of Urban Technology, 14(1), 77-91. https://doi.org/10.1080/10630730701260118

Deakin, M., \& Leydesdorff, L. (2013). The triple helix model of smart cities: A neo-evolutionary perspective. In M. Deakin (Ed.), Smart cities: Governing, modelling and analysing the transition (pp. 134-150). London: Routledge.

Falconer, G., \& Mitchell, S. (2012). Smart city framework: A systematic process for enabling smart + connected communities. CISCO Internet Business Solutions Group (IBSG). http://www.cisco.com/web/about/ ac79/docs/ps/motm/Smart-City-Framework.pdf

Frost \& Sullivan (2013). Strategic opportunity analysis of the global smart city market. Available at http://www.egr.msu.edu/ aesc310-web/ resources/SmartCities/Smart\%20City\%20Market\%20Report\%202.pdf

GhaffarianHoseini, A., Dahlan, N. D., Berardi, U., Ghaffarian Hoseini, A., Makaremi, N., \& GhaffarianHoseini, M. (2013). Sustainable energy performances of green buildings: A review of current theories, implementations and challenges. Renewable \& Sustainable Energy Reviews, 25, 1-17. https://doi.org/10.1016/j.rser.2013.01.010

Giffinger, R., Fertner, C., Kramar, H., Kalasek, R., Pichler-Milanovic, N., \& Meijers, E. (2007). Smart cities - ranking of European medium-sized cities. Wien: Vienna University of Technology.

Gooch, D., Wolff, A., Kortuem, G., \& Brown, R. (2015). Reimagining the role of citizens in smart city projects. Proceedings of the 2015 ACM International Joint Conference on Pervasive and Ubiquitous Computing and Proceedings of the 2015 ACM International Symposium on Wearable Computers. UbiComp '15 (New York, NY, USA: ACM). https://doi.org/10.1145/2800835.2801622

Greenfield, A. (2006). Everyware: The dawning age of ubiquitous computing. Boston: New Riders.

Hollands, R. G. (2008). Will the real smart city please stand up? City, 12(3), 303-320. https://doi.org/10.1080/13604810802479126

Ishida, T. (2002). Digital city Kyoto. Communications of the ACM, 45(7), 6-81. https://doi.org/10.1145/514236.514238

Klein, C., \& Kaefer, G. (2008). From smart homes to smart cities: Opportunities and challenges from an industrial perspective. In $S$. Balandin, D. Moltchanov, \& Y. Koucheryavy (Eds.), Next generation teletraffic and wired/wireless advanced networking, 1st Russian conference on smart spaces (ruSMART 2008) (pp. 260-261). Berlin Heidelberg, New York: Springer.

Komninos, N. (2008). Intelligent cities and globalisation of innovation networks. London and New York: Routledge.

Komninos, N. (2013). What makes cities intelligent? In M. Deakin, Smart cities: Governing, modelling and analysing the transition. London and New York: Taylor and Francis.

Komminos, N. (2015). The age of intelligent cities. Smart environments and innovation-for-all strategies. London and New York: Routledge. 
DRUŠ. ISTRAŽ. ZAGREB GOD. 26 (2017), BR. 4 STR. 519-538

NEVADO PEÑA, D., ALFARO NAVARRO, J. L., LÓPEZ RUIZ, V. R.: CASTILLA-LA MANCHA.
Kourtit, K., \& Nijkamp, P. (2012). Smart cities in the innovation age. Innovation: The European Journal of Social Science Research, 25(2), 93-95. https://doi.org/10.1080/13511610.2012.660331

Leydesdorff, L., \& Deakin, M. (2011). The triple-helix model of smart cities: A neo-evolutionary perspective. Journal of Urban Technology, 18(2), 53-63. https://doi.org/10.1080/10630732.2011.601111

Lombardi, P., Giordano, S., Caragliu, A., Del Bo, C., Deakin, M., Nijkamp, P., Kourtit, K., \& Farouh, H. (2011). An advanced triple-helix network model for smart cities performance. In O. Yalciner Ercoskun (Ed.), Green and ecological technologies for urban planning: Creating smart cities (pp. 59-72). Hershey, PA: IGI Global.

López-Ruiz, V. R., Alfaro-Navarro, J. L., \& Nevado-Peña, D. (2014). Knowledge-city index construction: An intellectual capital perspective. Expert Systems with Application, 41(12), 5560-5572. https://doi.org/ 10.1016/j.eswa.2014.02.007

Nam, T., \& Pardo, T. (2011). Smart city as urban innovation: Focusing on management, policy, and context. Proceedings of the 5th International Conference on Theory and Practice of Electronic Governance, ACM, Tallin, 26-28 September. https://doi.org/10.1145/2072069.2072100

Neirotti, P., De Marco, A., Cagliano, A. C., Mangano, G., \& Scorrano, F. (2014). Current trends in smart city initiatives: Some stylised facts. Cities, 38, 25-36. https://doi.org/10.1016/j.cities.2013.12.010

Romer, P. M. (1986). Increasing returns and long-run growth. The Journal of Political Economy, 94(5), 1002-1037. https:/doi.org/10.1086/ 261420

Schiuma, G., \& Lerro, A. (2008). Knowledge-based capital in building regional innovation capacity. Journal of Knowledge Management, 12(5), 121-136. https://doi.org/10.1108/13673270810902984

Schuler, D. (2002). Digital cities and digital citizens. In M. Tanabe, P. van den Besselaar, \& T. Ishida (Eds.), Digital cities II: Computational and sociological approaches (pp. 71-85). Berlin Heidelberg: Springer-Verlag. https://doi.org/10.1007/3-540-45636-8_6

Townsend, A. M. (2013). Smart cities: Big data, civic hackers, and the quest for a new utopia. New York: W. W. Norton \& Company.

Uziene, L. (2013). City's intellectual capital framework: The performance measurement point of view. Economics and Management, 18(2), 198-208. https://doi.org/10.5755/j01.em.18.2.4761

Washburn, D., Sindhu, U., Balaouras, S., Dines, R. A., Hayes, N. M., \& Nelson, L. E. (2010). Helping CIOs understand "smart city" initiatives: Defining the smart city, its drivers, and the role of the CIO. Cambridge, MA: Forrester Research. 
DRUŠ. ISTRAŽ. ZAGREB GOD. 26 (2017), BR. 4, STR. 519-538

NEVADO PEÑA, D. ALFARO NAVARRO,' J. L., LÓPEZ RUIZ, V. R.: CASTILLA-LA MANCHA.

\section{Konkurentnost intelektualnog kapitala gradova pokrajine Castilla-La Mancha u usporedbi s drugim španjolskim gradovima}

Domingo NEVADO PEÑA

Fakultet prava i društvenih znanosti, Sveučilište Castilla-La Mancha, Ciudad Real, Španjolska

José Luis ALFARO NAVARRO, Víctor Raúl LÓPEZ RUIZ

Fakultet ekonomije i poslovnog upravljanja, Sveučilište Castilla-La

Mancha, Albacete, Spanjolska

Intelektualni kapital ima središnju ulogu u pametnim gradovima. Cili je ovoga rada primijeniti nedavno razvijeni model utemeljen na intelektualnom kapitalu u mjerenju konkurentnosti gradova i u upravlianju njihovim materijalnim i nematerijalnim bogatstvom. Model je primijenjen u gradovima pokrajine Castilla-La Mancha i u još 19 španjolskih gradova, omogućujući njihovu usporednu analizu. U tom smislu studija je sintetički pokazateli koji omogućuje rangiranje španjolskih gradova na temelju dostupnih podataka i predlaže sveobuhvatnu strategiju upravljanja njihovim materijalnim i nematerijalnim bogatstvima. Iz rezultata se može zaključiti da gradovi pokrajine Castilla-La Mancha imaju izvrsne ljudske resurse i dobru kvalitetu života, ali da postoji prostor za poboljšanja u pogledu gradske infrastrukture i planiranja.

Ključne riječi: pametan grad, grad znanja, intelektualni kapital, indeks, nematerijalno bogatstvo, model, konkurentnost

\section{(c) (i) ()}

Međunarodna licenca / International License:

Creative Commons Attribution-NonCommercial-NoDerivatives 4.0. 